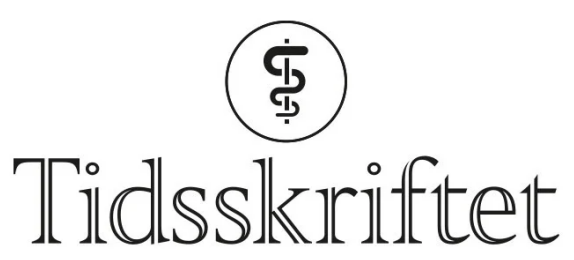

DEN NORSKE LEGEFORENING

\title{
En kvinne i 70-årene med akutt blindhet
}

NOE Å LARE AV

\section{RUTH SLETTEBERG}

uxruet@ous-hf.no

Nevroradiologisk avdeling

Oslo universitetssykehus, Rikshospitalet

Ruth Sletteberg er spesialist i radiologi og overlege. Hun jobber i team for nevrovaskulær intervensjon.

Forfatter har fylt ut ICMJE-skjemaet og oppgir ingen interessekonflikter.

\section{KAJA NORDENGEN}

Nevrologisk avdeling

Oslo universitetssykehus, Ullevål

Kaja Nordengen er postdoktor og lege i spesialisering. Under den beskrevne problemstilling var hun i spesialisering ved Nevrokirurgisk avdeling, Rikshospitalet.

Forfatteren har fylt ut ICMJE-skjemaet og oppgir ingen interessekonflikter.

\section{WILHELM SORTEBERG}

Nevrokirurgisk avdeling

Oslo universitetssykehus, Rikshospitalet

Wilhelm Sorteberg er dr.med., spesialist i nevrokirurgi og overlege. Han har i mange år ledet avdelingens nevrovaskulære seksjon.

Forfatteren har fylt ut ICMJE-skjemaet og oppgir ingen interessekonflikter.

\section{EVA ASTRID JACOBSEN}

Radiologisk avdeling/nevroradiologi

Universitetssykehuset Nord-Norge

Eva Astrid Jacobsen er dr.med., spesialist i radiologi og overlege. Hun er konsulent for avdeling for Bildediagnostikk, Akershus universitetssykehus. Under den beskrevne problemstilling var hun overlege ved Nevroradiologisk enhet, Oslo universitetssykehus, Rikshospitalet og fagansvarlig for nevrovaskulær intervensjon.

Forfatteren har fylt ut ICMJE-skjemaet og oppgir ingen interessekonflikter.

\section{En kvinne i 7o-årene ble utredet for en pulssynkron suselyd i øret. To timer senere ble hun brått blind på begge øynene.}

Kvinnen hadde $i$ to år hatt en pulssynkron suselyd $i$ venstre øre. Lyden var alltid til stede og svart plagsom. Den gav søvnproblemer, slik at hun brukte sovemedisin og måtte ha på bakgrunnsmusikk for å overdøve lyden om natten. 
På regionssykehuset var hun blitt utredet med MR caput, som hadde vist T2-høysignalforandringer $i$ hvit substans av uspesifikk art. Det var ingen øvrige patologiske funn. Regionssykehuset hadde også utredet med digital subtraksjonsangiografi (injeksjon i venstre arteria carotis communis og selektiv injeksjon i venstre a. occipitalis), som hadde vist en kranial dural arteriovenøs fistel ved venstre sinus sigmoideus med arterietilførsel fra venstre a. occipitalis.

En kranial dural arteriovenøs fistel er en unormal direkte åpning fra arterie til vene i dura mater. En arterie som i utgangspunktet har sitt forsyningsområde ekstraduralt eller i selve dura, vil da tømme seg direkte i en av hjernens vener eller venesinus. En kranial dural arteriovenøs fistel kan være idiopatisk eller assosiert med tidligere gjennomgått sinusvenetrombose, kraniotomi eller hodetraume (1). Den kan gi symptomer ved at pasienten hører blodstrømmen som går gjennom fistelen, som en pulssynkron suselyd. Pasienten kan også få symptomer som følge av økt intrakranialt venetrykk (som hodepine, epileptiske anfall eller fokale nevrologiske utfall etter fistelens lokalisasjon), eller symptomer sekundært til at øyets vener tas i bruk som drenasjevei (eksoftalmus, kjemose, synsforstyrrelse). I sjeldne tilfeller kan fistelen gi hjerneblødning. En kranial dural arteriovenøs fistel kan også være asymptomatisk (2).

Durale arteriovenøse fistler undersøkes best ved digital subtraksjonsangiografi. Det er en invasiv undersøkelse der man via et kateter i lysken eller armen injiserer kontrast selektivt intraarterielt i a. carotis interna, a. carotis externa og a. vertebralis, inklusiv grener. Ved digital subtraksjonsangiografi avbildes kontrastens passasje gjennom kartreet.

Tidsoppløsningen er bedre enn ved CT- og MR-angiografi og gir en god dynamisk fremstilling av blodstrøm. Dette er nyttig særlig ved kartlegging av arteriovenøs shunting. Digital subtraksjonsangiografi har også bedre romlig oppløsning/ detaljfremstilling enn både CT og MR.

Pasienten ble innlagt på nevrokirurgisk avdeling for planlagt utredning med tanke på behandling av fistelen. Hun brukte daglig $8 \mathrm{mg}$ kandesartan per os mot høyt blodtrykk og hadde kostregulert diabetes mellitus type 2. Blodtrykket hennes var ved innleggelsen 166/75 $\mathrm{mm} \mathrm{Hg}$, og ved klinisk unders $ø$ kelse var det normal organstatus, inkludert normal nevrologisk status. Hun hadde normale funn på orienterende blodprøver, bortsett fra lett forhøyede verdier av natrium på $146 \mathrm{mmol} / \mathrm{l}$ (referanseområde 137-144 mmol/L), C-reaktivt protein på 4,6 mg/L (referanseområde < $4 \mathrm{mg} / \mathrm{L}$ ) og glukose 8,o mmol/L (referanseverdi 4,2-6,3 $\mathrm{mmol} / \mathrm{L}$ ).

På nevroradiologisk avdeling ble det utført digital subtraksjonsangiografi med superselektiv kateterisering bilateralt $i$ a. carotis interna, a. carotis externa med grener og $a$. vertebralis. Det ble injisert et normalt volum (120 ml) av det ikke-ioniske kontrastmiddelet jomeprol $300 \mathrm{mg} / \mathrm{ml}$. Kateteriseringen forløp ukomplisert og i normalt tempo. Detaljkartleggingen viste at høyre og venstre a. occipitalis, venstre a. meningea media (grener av a. carotis externa) samt muskelgrener fra venstre a. vertebralis forsynte fistelen. Fistelstedet lå i veggen av venstre sinus sigmoideus med antegrad blodstrøm i venesinus og ned i venstre vena jugularis interna.

Etter at pasienten hadde gjennomgått digital subtraksjonsangiografi ble hun sendt tilbake til nevrokirurgisk sengepost. To timer senere endret det kliniske bildet seg dramatisk. Det oppsto akutt blindhet på begge øynene, hodepine og forvirring med hallusinasjoner.

Man fikk ikke testet øyebevegelser, men gjennomførte øvrig nevrologisk undersøkelse med synstester. Pupillene var sidelike og lysreagerende, men det var komplett synstap på begge øynene. Pasienten anga selv at hun så normalt til tross for at objektive tester viste at hun ikke gjorde det. Utenom synstapet og forvirringen var det normal nevrologisk status.

Man vurderte vaskulær komplikasjon som årsak til symptomene. Ved akutt oppstått blindhet kan årsaken være en embolus til a. retinalis (en gren av a. ophthalmica som forsynes fra både a. carotis interna og a. carotis externa). Imidlertid er det lite sannsynlig å få bilaterale retinale embolier med blindhet uten samtidig å få embolier i hjernearterier og dermed flere nevrologiske utfall. Symptomene kunne også komme fra synsbarken (oksipitalt) som får sin blodtilførsel fra a. cerebri posterior (forsynt fra a. basilaris eller fra a. carotis interna via a. communicans posterior). 
30 minutter etter at hun ble akutt blind, ble det tatt CT caput og CT-angiografi av intrakraniale arterier. CT caput viste utbredt diffus kontrastoppladning i synsbarken (oksipitalt) bilateralt, men ingen blødning eller infarkt (figur 1). CT-angiografi viste ingen karokklusjon eller karspasmer. Som forventet ved en kranial dural arteriovenøs fistel var det økte kartegninger og arterialisert kontrastfylning $i$ durale vener.

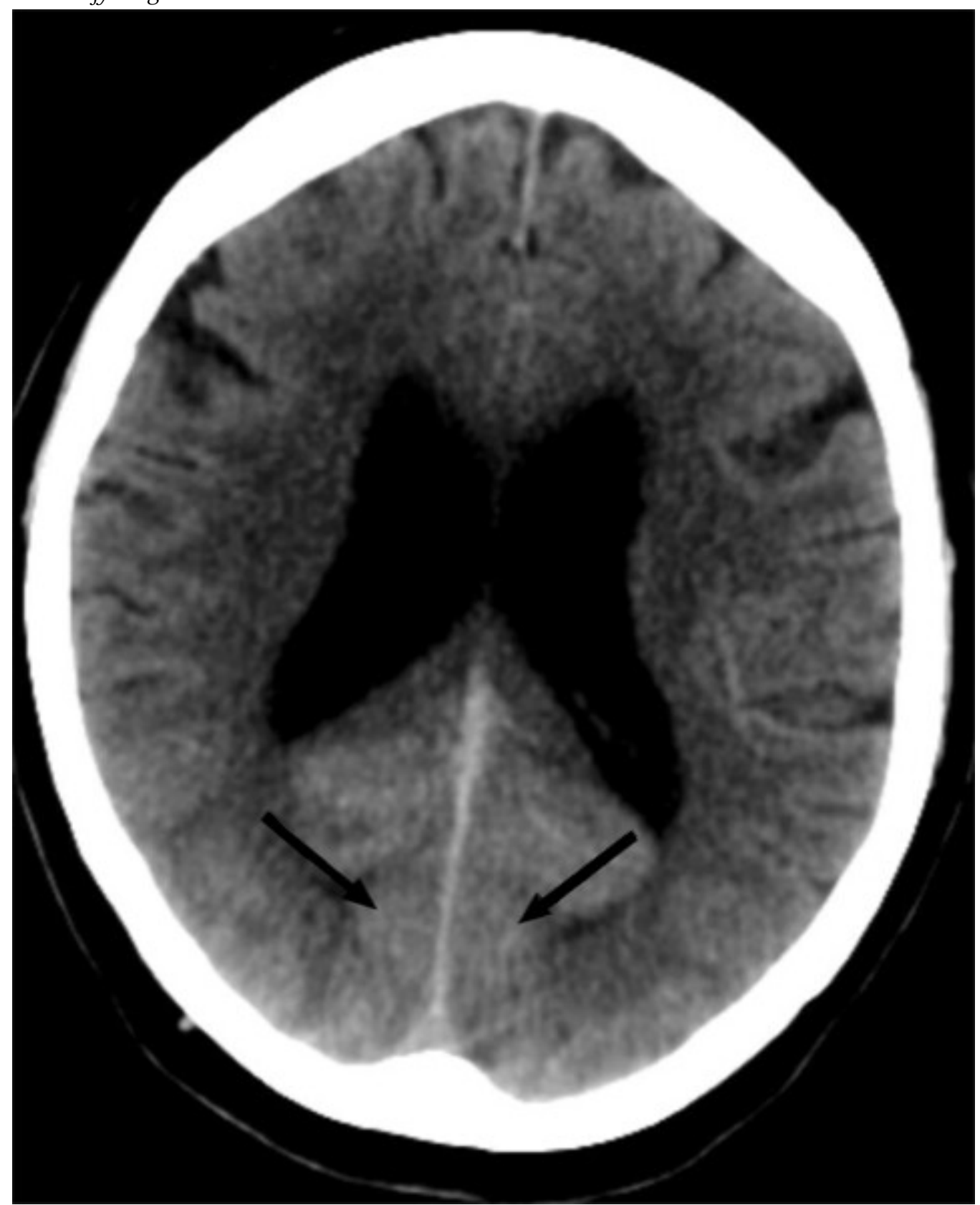

Figur 1 CT caput viser diffus utbredt kontrastretensjon oksipitalt bilateralt, inkludert i synsbarken. Ingen blødning eller infarkt.

MR caput (T1- og T2-vektede sekvenser, FLAIR-sekvenser og diffusjon med ADC-verdier (apparent diffusion coefficient)) utført rett etter CT-undersøkelsen viste som tidligere uspesifikke T2- høysignal lesjoner, men ingen nytilkomne forandringer (figur 2). Det var ingen diffusjonsrestriksjon, som er forventet ved ferskt hjerneinfarkt (3): 


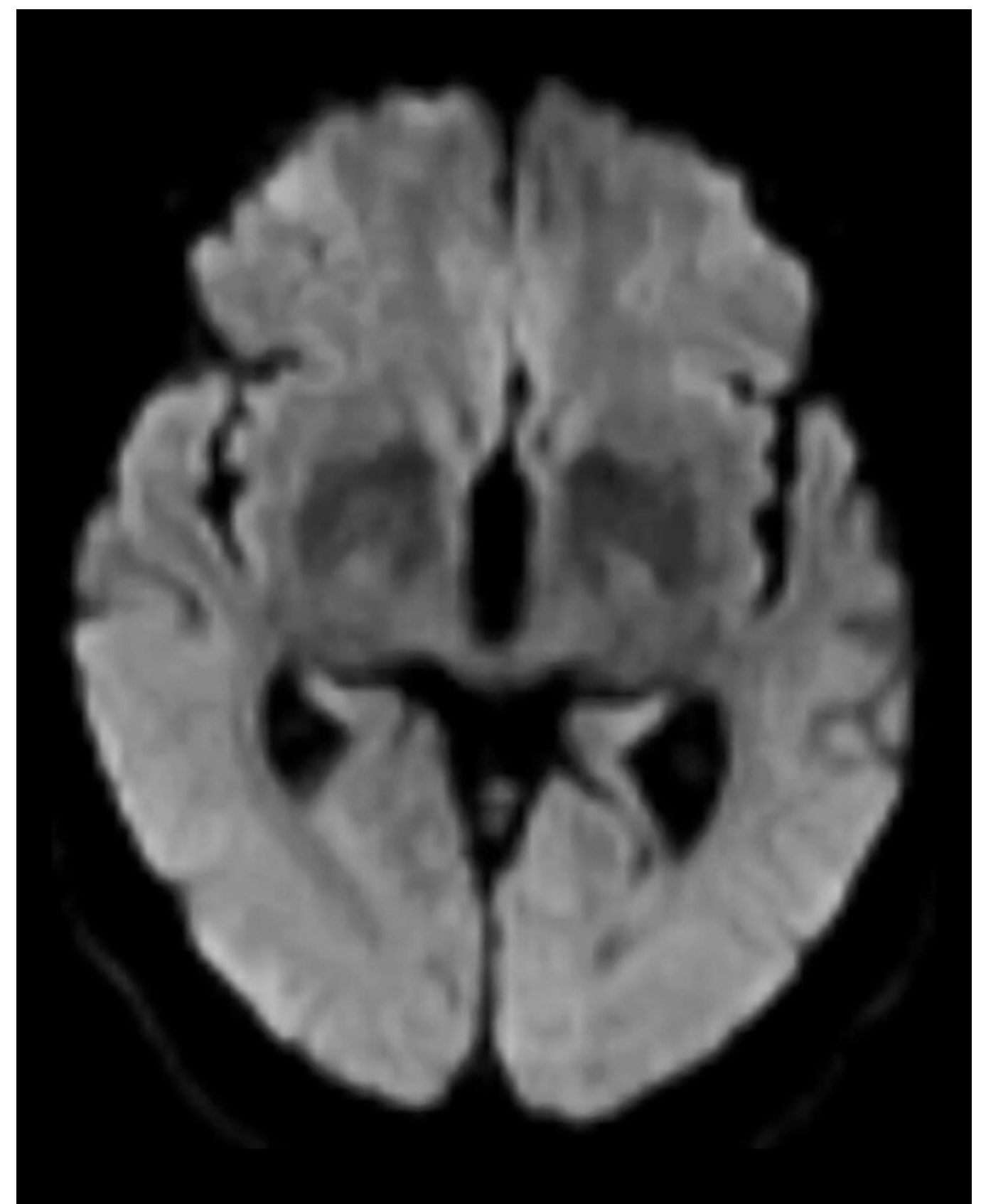

Figur 2 MR caput viser ingen diffusjonsforandringer.

På pasientens CT-bilder var det retensjon av kontrast i synsbarken på begge sider. CTbildene var gjort uten kontrast, så den synlige kontrasten måtte være fra konvensjonell cerebral angiografi gjort to timer tidligere. CT-angiografi viste åpne kar. På MR var det ingen nytilkomne signalforandringer. De kliniske symptomene sammen med bildefunnene passet dermed ikke med cerebral iskemi på bakgrunn av tromboembolisme eller karspasmer.

Pasientens øvrige sykdommer, hypertensjon og diabetes mellitus type 2, ble nøye monitorert for å utelukke disse som bidragende faktorer.

Blodtrykket ved innleggelsen var $166 / 75 \mathrm{~mm} \mathrm{Hg}$, men ved symptomdebut to timer etter den angiografiske undersøkelsen var det systoliske blodtrykket 170-19o mm Hg. Hun ble behandlet med $5 \mathrm{mg}$ labetolol intravenøst $i$ alt tre ganger. Dette hadde god effekt på blodtrykket, og ett døgn etter at hun ble akutt blind, var blodtrykket 140-150/6o-8o mm Hg. Blodsukkerverdiene varierte under oppholdet mellom 6,1 $\mathrm{mmol} / \mathrm{L}$ og 8,5 $\mathrm{mmol} / \mathrm{L}$.

Epileptisk aktivitet i synsbarken ble vurdert som en mulig forklaring på synsforstyrrelsen. Riktignok var det ikke andre kliniske funn som støttet dette. 
Med bakgrunn i denne vurderingen ble det gjort en standard EEG-undersøkelse. Denne viste patologi med intermitterende langsom deltaaktivitet, bilateralt og sidevekslende, mest uttalt frontalt. Det var videre sannsynlig epileptiform aktivitet og rikelig langsom aktivitet parietooksipitalt på venstre side. EEG-funnene ble tolket som en generell påvirkning av hjernen med irritative elementer oksipitalt. Man vurderte at dette ikke ga støtte til epileptisk genese.

Ett døgn etter hendelsen med synstap ble det gjort ny nevrologisk undersøkelse. Det var fortsatt komplett synstap på begge øynene. Man fikk nå testet ekstraokulcere bevegelser, og de var intakte. Pupillreflekser var til stede. Hun var mindre forvirret enn dagen før og forsto og anga selv at hun ikke kunne se.

Etter to døgn hadde forvirringen avtatt ytterligere, og hun fortalte at synet hadde begynt å komme tilbake. Ny MR caput viste at det var tilkommet to punktformige lesjoner frontoparietalt med diffusjonsrestriksjon som ved små ferske emboliske infarkter. For øvrig var det normale MR-funn. Ved konvensjonell angiografi sendes hyppig små embolier ut i sirkulasjonen, og man kan få små infarkter i hjernen etter en slik prosedyre. Embolier som gir forbigående lette nevrologiske utfall etter cerebral angiografi, er rapportert å forekomme hos 0,9-4\% (4). Stille embolier som ikke gir nevrologiske utfall, men som kan sees som tilkomne små lesjoner med diffusjonsrestriksjon på MR etter angiografi, er rapportert hos 15-26\% (5). Grunnet lesjonenes lokalisasjon kunne disse ikke forklare pasientens symptomer.

Fire døgn etter hendelsen var pasienten ikke lenger forvirret, men hun opplevde blinking og skjelving på begge øynene. Etter seks døgn var hun klar og orientert og hadde fått tilbake normalt syn. Hun ble samme dag utskrevet til hjemmet i påvente av elektiv behandling av sin kraniale, durale arteriovenøse fistel.

Indikasjon for behandling av en kranial, dural arteriovenøs fistel bestemmes ut fra pasientens kliniske symptomer og radiologiske funn. Valg av type behandling, endovaskulær eller kirurgisk (eventuelt i kombinasjon), avgjøres i samarbeid mellom nevroradiolog og nevrokirurg. Dersom fistelen kan lukkes via endovaskulær tilgang, er denne behandlingsformen gjerne førstevalget.

Hos vår pasient var fistelen ikke tilgjengelig for endovaskulær behandling via tilførende arterier. På venesiden drenerte fistelen direkte i venesinus og ikke i en separat venelomme som kunne ha blitt lukket endovaskulært. Selve venesinus kunne man ikke lukke, fordi den var drenasjevei også for hjernens parenkym. Det ble planlagt kirurgi.

Hun ble på et senere tidspunkt behandlet kirurgisk ved at fistelen og deler av venstre sinus sigmoideus ble ekstirpert. Ved poliklinisk kontroll tre måneder etter operasjon hadde hun normal nevrologisk status og var helt kvitt sin plagsomme pulssynkrone bilyd.

\section{Diskusjon}

De kliniske og radiologiske funnene hos vår pasient er typiske ved et svært sjeldent, men kjent fenomen kalt akutt blindhet etter angiografi (transient cortical blindness). Denne bivirkningen etter digital subtraksjonsangiografi ble beskrevet første gang i 1970 (므). Blindheten oppstår fra få minutter til 12 timer etter den angiografiske unders $ø$ kelsen, og symptomene går helt tilbake innen 4-5 døgn.

Det er en sjelden bivirkning etter cerebral digital subtraksjonsangiografi og enda noe sjeldnere etter koronar angiografi. Det er beskrevet å oppstå hos o,35 \% etter cerebral digital subtraksjonsangiografi (7.).

Transient kortikal blindhet forekommer svært sjelden, og det er få publikasjoner om temaet, de fleste er kasuistikker. I 2019 ble det imidlertid publisert en multisenterstudie der 18 av 5126 pasienter opplevde denne bivirkningen. Total kontrastdose, utført kontrastinjeksjon i bakre kretsløp og lav kroppsvekt ble funnet å være risikofaktorer (7.).

Det er ikke vist $ø$ kt sannsynlighet for gjentagelse av transient kortikal blindhet hos samme pasient ved ny digital subtraksjonsangiografi. Lidelsen er selvbegrensende, og det verken finnes eller er behov for noen behandling av symptomene. 
Dette er en eksklusjonsdiagnose. MR caput og eventuelt CT caput med CT-angiografi er indisert for å utelukke blødning eller iskemisk årsak til synsaffeksjon. MR kan være negativ eller vise høysignal på T2- og FLAIR-signaler som ved vasogent ødem. CT kan vise normale funn eller kontrastoppladning oksipitalt. CT-angiografi fremstiller åpne kar uten spasmer.

Mekanismen bak transient kortikal blindhet etter digital subtraksjonsangiografi er ikke kjent. Det er sett likheter med mekanismen bak posterior reversibel encefalopati-syndrom (PRES) ( ). Denne tilstanden er lokalisert i forsyningsområdet til a. cerebri posterior og kan ha sammenheng med mindre utviklet sympatikusinnervasjon i det vertebrobasilære arteriesystemet enn i carotisarteriesystemet, og derfor mindre evne til sympatikusmediert vasokonstriksjon som beskyttelse ved hypertensjon (9.). Det er vurdert slik at blod-hjerne-

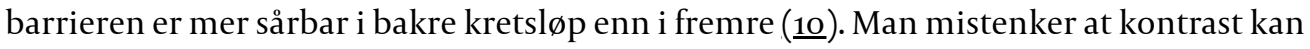
indusere endoteldysfunksjon med forbigående brudd i blod-hjerne-barrieren og at kontrast da kan ha nevrotoksisk effekt med forbigående påvirkning av nevronal aktivitet $(\underline{11}, \underline{12})$.

Sykehistorien til vår pasient illustrerer godt de kliniske og radiologiske funnene ved tilstanden. Den er også en påminnelse til radiologer og klinikere på avdelinger der det gjøres cerebral digital subtraksjonsangiografi eller koronar angiografi.

Pasienten har samtykket til at artikkelen blir publisert. Artikkelen er fagfellevurdert.

\section{LITTERATUR}

1. Gandhi D, Chen J, Pearl M et al. Intracranial dural arteriovenous fistulas: classification, imaging findings, and treatment. AJNR Am J Neuroradiol 2012; 33: 1007-13. [PubMed][CrossRef]

2. Borden JA, Wu JK, Shucart WA. A proposed classification for spinal and cranial dural arteriovenous fistulous malformations and implications for treatment. J Neurosurg 1995; 82: 166-79. [PubMed] [CrossRef]

3. Stadnik TW, Demaerel P, Luypaert RR et al. Imaging tutorial: differential diagnosis of bright lesions on diffusion-weighted MR images. Radiographics 2003; 23: e7. [PubMed][CrossRef]

4. Kaufmann TJ, Huston J, Mandrekar JN et al. Complications of diagnostic cerebral angiography: evaluation of 19,826 consecutive patients. Radiology 2007; 243: 812-9. [PubMed][CrossRef]

5. Brockmann C, Seker F, Weiss C et al. Acetylsalicylic acid does not prevent digital subtraction angiography-related high signal intensity lesions in diffusion-weighted imaging in cerebrovascular patients. A retrospective analysis. Clin Neuroradiol 2012; 22:15-20. [PubMed][CrossRef]

6. Fischer-Williams M, Gottschalk PG, Browell JN. Transient cortical blindness. An unusual complication of coronary angiography. Neurology 1970; 20:353-5. [PubMed][CrossRef]

7. Li M, Liang H, Liu C et al. Risk factors of transient cortical blindness after cerebral angiography: a multicenter study. Front Neurol 2019; 10:1005. [PubMed][CrossRef]

8. Saigal G, Bhatia R, Bhatia S et al. MR findings of cortical blindness following cerebral angiography: is this entity related to posterior reversible leukoencephalopathy? AJNR Am J Neuroradiol 2004; 25: 252-6. [PubMed]

9. Edvinsson L, Owman C, Sjöberg NO. Autonomic nerves, mast cells, and amine receptors in human brain vessels. A histochemical and pharmacological study. Brain Res 1976; 115: 377-93. [PubMed] [CrossRef]

10. Merchut MP, Richie B. Transient visuospatial disorder from angiographic contrast. Arch Neurol 2002; 59: 851-4. [PubMed][CrossRef]

11. de Falco A, De Simone M, d'Onofrio F et al. Posterior reversible encephalopathy syndrome overlapping contrast-induced encephalopathy after coronary angiography. Neurol Sci 2019; 40: 1951-3. [PubMed][CrossRef]

12. Sharp S, Stone J, Beach R. Contrast agent neurotoxicity presenting as subarachnoid hemorrhage. Neurology 1999; 52: 1503-5. [PubMed][CrossRef]

Publisert: 27. september 2021. Tidsskr Nor Legeforen. DOI:10.4045/tidsskr.20.1034

Mottatt 17.12.2020, første revisjon innsendt 15.3.2021, godkjent 28.4.2021. 
Publisert under åpen tilgang CC BY-ND. Lastet ned fra tidsskriftet.no 26. april 2023. 